\title{
A Granger Causal Analysis of Tax-Spend Hypothesis: Evidence from Malaysia
}

\author{
Hanana Khan $^{1,2}$, Maran Marimuthu, ${ }^{1, *}$, and Fong-Woon Lai ${ }^{1}$ \\ ${ }^{1}$ Deparment of Management and Humanities, Universiti Teknologi PETRONAS, 32610 Seri \\ Iskandar, Perak, Malaysia \\ ${ }^{2}$ Deparment of Economics, Kohat University of Science and Technology, 26000 Kohat, Pakistan
}

\begin{abstract}
In economics, the investigation of the association between government revenues (GR) and government expenditures (GE) remains an essential discussion because of its vital role in policy implication concerning the Budget deficit. This paper aims to conduct a causal analysis of these two fiscal variables (government revenue and expenditure) using financial time-series data covering the period from 1990 to 2019 of Malaysia. The analyses used the unit root, Johanson Cointegration, and the Vector Error Correction Model (VECM). Unit root test proposed tested variables are integrated at a level first. Johanson's cointegration test disclosed the fact that long-run relationships exist between the tested variable. Finally, Granger causality analysis reveals a one-way relation between government revenues and expenditures and this unidirectional association is from revenues to expenditures which indicates that in Malaysia, expenditures are supported by revenues; in other words, the Taxspend hypothesis is supported. In VECM short-run analysis, government revenues can affect government expenditures significantly and $11 \%$ disequilibrium can be corrected in the short-run. In short-run and long-run revenues are supporting expenditures. The study recommends that to avoid a high risk of economic problems like a fiscal illusion, unnecessary financial burden, and inflation policymakers should not be imposing a high tax rate to cut the budget deficit.
\end{abstract}

\section{Introduction}

Fiscal policy plays a crucial role in developing countries, including those in Southeast Asia. This role takes account of financing the developmental and current budget of the government, balancing national income and output. Large quantities of resources must be raised and spent efficiently. Moreover, the gap (usually negative) between public expenditure and revenues must be recoverable in the sense that the ratio between debt and Gross Domestic Product (GDP) of a government must be low or having a finite limit.

A crisis can challenge the economic growth of a country by destroying the financial condition (Reinhart \& Rogoff, 2010). Households, firms, and government are generally over-borrowed in this period, which creates a disturbance in the financial sector of the

\footnotetext{
* Corresponding author: maran.marimuthu@utp.edu.my
} 
country (Buttiglione, Lane, Reichlin, \& Reinhart, 2014). In the Asian financial Crisis of 1997, much attention has been generated among Asian countries, including Malaysia, to reconsider their fiscal policy as an alternative macroeconomic tool to keep stable their economy.

The importance of government expenditures and revenues (onwards government expenditures and revenues will be referred to as GE and GR, respectively) is reported by (Narayan \& Narayan, 2006) with three key reasons: 1) if the hypothesis of tax-spend is maintained, then the government first collect revenue by taxation and spend whatever is made accessible later, it depends on the causality relationship between variables whether it is positive or negative causality. 2) Just in case a two-way causality does not exist, this indicates that the decisions on government revenues are taken without considering expenditure decisions. This may lead to a budget deficit, rapid upsurges in government expenditures than government revenues. 3) If the hypothesis of spend-tax is maintained, this indicates that the government spends first by increasing taxation at a later stage. This will involve the concern with promoting the outflow of capital and paying earnings in the future.

In Malaysia, government expenditures have steadily exceeded government revenues throughout the past decade. In the Asian financial crisis, 1997-1998 Malaysian economic growth hovered around 5\% to $6 \%$ annually. To undergo economic growth, Malaysia's government implemented an expansionary fiscal policy in the late 1990s, which has degraded the budget deficit. The budget deficit in 2007 mounted at 3.2\% of GDP. The government's assurance in tracking rapid economic development in five-year Malaysian development plans is mainly responsible for fiscal deficits. The fiscal deficit has a significant impact on the economy as it leans towards the reduction in national savings which leads to the economic downturn. Two options are available for stimulating economic growth in a budget deficit economy, i.e., reducing expenditures or increasing tax revenues.

In Malaysia, per capita, government expenditure is higher relative to other bordering countries. Federal government per capita expenditures of Malaysia are higher than Indonesia, the Philippines, and Thailand (Chee, 1990).

From Figure 1, it can be observed that after the Asian crisis in 1998, expenditures are higher than revenues. It is essential to investigate the direction of fiscal variables, whether government expenditure is regulating by government revenues or revenue is controlled by government expenditure (Friedman, 1978). Thus, it is necessary to know that government expenditures are directly related to economic growth, or it is regulating by revenues. The benefit of knowing this is to target the specific fiscal variable in the right direction at the right time; then, hopefully, fiscal policy will be useful. Malaysia is facing a budget deficit since 1998. It is crucial to dig down the causal relation between expenditures and revenues because there is an imbalance between them; that is why Malaysia is facing a budget deficit for a long time. After investigating the causal relationship, the study can recommend future policy to cut the budget deficit. To find out the causality direction between government revenues (GR) and government expenditures (GE) along with implications to manage the budget deficit is the main objective of this study. Further, this study investigates the longrun and short-run relationships between GR and GE. 


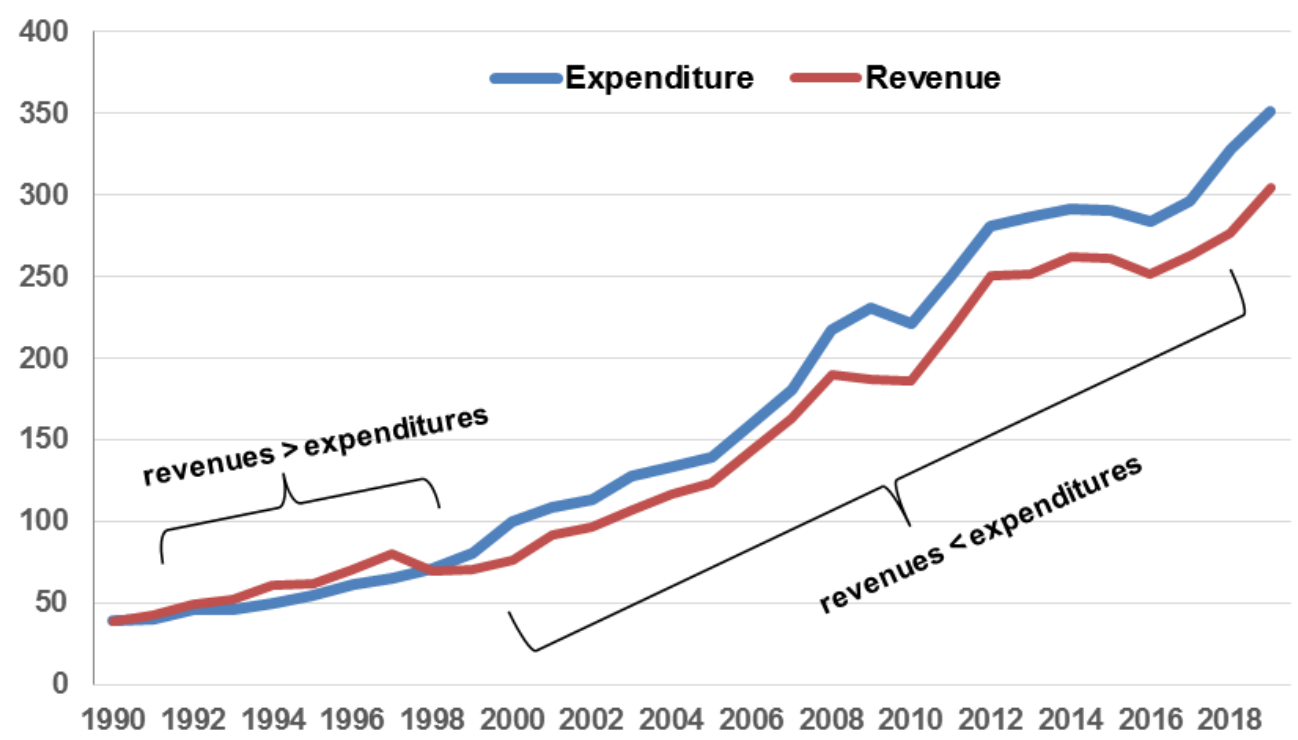

Fig. 1. Past fiscal tendencies in Malaysia (x-axis refers to years, and the $y$-axis indicates the Dollars amount in million)

\section{Literature Review}

\subsection{Theoretical Background}

In theory, tax-spending has brought for its relationship between public spending and revenues into account three hypotheses. The first tax-spending hypothesis suggested by (Friedman, 1978) states that the increase in taxes, raising the price of the resources accessible to the public sector to reduce the budget deficit, means a rise in GE. If revenue has a constructive effect on expenses, then revenue reduction will lead to cost reduction. An alternative point of view to this hypothesis is formulated by BW (Buchanan \& Wagner, 1977). Consistent with their opinion, a rise in revenue will cause a decrease in spending through the fiscal illusion which arises when there is an inverse causal relationship from revenues to expenditures, the tax increase may reduce government expenditures, and tax decrease may increase government expenditures. A tax increase can make taxpayer more aggressive towards government expenditure by lowering their quantity demand and formed a substitution effect while tax reduction can increase quantity demand towards government spending.

Second, the expenditure-tax hypothesis indicates that alterations in revenue and taxation policies are determined by expenditure decisions. Considering that the Ricardian equivalence proposition what authorities borrow now will become obligations for future taxation, which can be adequately capitalized by taxpayers, (Barro, 1979) assumed the nonexistence of fiscal illusion concept believed from the BW. Under the Ricardian equivalence model, the gain in public expenditures contributes to a rise in taxation. Besides, (Roberts, 1978) along with (Peacock \& Wiseman, 1979) recommended that short-run (temporary) growth in public spending due to emergency cases contributes to high taxes permanently (Hypothesis of displacement effect). Hence, according to this expenditure-tax hypothesis, the decrease in public spending will result in a decrease in deficits. 
Third, according to the fiscal synchronization hypothesis, decisions on expenditures and revenue are formed at the same time or conjointly. The policy-makers analyse the additional benefits and costs of government agendas once deciding the proper grade of public spending and revenue, as proposed by (Musgrave, 1966) and (Meltzer \& Richard, 1981). The hypothesis of institutional separation proposed by (Baghestani \& McNown, 1994) discloses that taxation conclusions are somewhat autonomous in the case of public expenditure.

\subsection{Empirical Literature Review}

The causal connections between GE and GR were investigated by (Hong, 2009) in Malaysia by applying the Cointegration and the Error correction model (ECM). The study observed a long-run association between the tested variables and supported the spend-tax hypothesis. Another study reported the association between government spending and revenues in multiple Asian countries over the time span of 1995 to 2008 by using Panel unit root and cointegration techniques (Mehrara, Pahlavani, \& Elyasi, 2011). The study concluded that the Bidirectional relationship or fiscal synchronization hypothesis is supported in many Asian countries. Another study reported the causality relationship between government expenditures and revenues using VAR models from the period 1970 to 2006 (Loganathan \& Taha, 2007). Results supported unidirectional and bidirectional relationships between expenditures and revenues. Similarly, it is reported that a significant portion of government revenues come from taxation and expenditures get affected by indirect tax revenues (Ullah, 2016). A study that examined the association between government revenue and expenditures in Qatar from the period 1980 to 2011, suggested a unidirectional relation, tax-spend hypothesis (Al-Khulaifi, 2012), supporting the tax-spend hypothesis in the middle-east economy.

Aslan and Taşdemir (Aslan \& Taşdemir, 2009) used cointegration and causality frameworks alongside endogenously structural breaks with many alternate lags to search out the dynamic and causative relationship of Turkish government spending and revenue patterns for the period 1950-2007. The study concluded that in the last fifty years of the Turkish government, the fiscal synchronization hypothesis is compatible with public finance performance. Irandoust (Irandoust, 2018) investigated the causal connection between the expenditure and government revenues in Sweden covering the period from 1722 to 2011. The author employed the cointegration method along with Granger's noncausality evaluation and reported the existence of a long run that association between GE and GR. In addition, the two-way association between expenditures and revenue is consistent with the synchronization hypothesis. The research concluded that the improvement in budget deficit could be achieved by government expenditure cut combined with simultaneous tax controls.

Mutascu examined the relationship between government revenues and public spending in the case of 10 former EU communist countries; the result shows a one-way association between government spending and revenue (Mutascu, 2015). Fasano and Wang (Fasano \& Wang, 2002) examined the direction of causality between revenue and government expenditure by using cointegration, error correction model, and variance decomposition analysis in Gulf Cooperation Council (GCC) countries. The expenditure dominance hypothesis has been supported as expenditure policy can vary oil revenue in GCC countries. Jalil and Harun (Jalil \& Harun, 2012) worked on Malaysia's two state governments, namely Penang and Kelantan, and used the Autoregressive distributed lag model (ARDL) or bound test for the cointegration relationships. Their findings showed consistent results in the state of Kelantan with the tax and spend hypothesis; while in the 
state of Penang, the results did not show any causal relationship between its expenditure and revenue in the short run.

\section{Data and Methodology}

In this analysis, the annual time series data collected from the World Bank database comprises the time span of 29 years (from 1990 to 2019). The data was transformed in log form to stabilize the variance of the time series. Three variables are used in the analysis: 1) government expenditures (GE), which comprises the household final consumption expenditures, general government final consumption expenditures and the gross capital formation (formerly gross domestic investment expenditures), 2) government revenues (GR), it covers the cash receipts from taxes, social contributions and additional revenues including fines, fees, rent and income from property or sales, and 3) is the gross domestic product (GDP), which is used because GR and GE are related to the overall economic growth. The addition of GDP eliminates the problematic spurious causal properties because of the omission of significant variables from the examined association.

To achieve the objectives of this analysis, i.e., evaluation of the association between GE and GR, the three variables model has been formulated. There are three steps to find out the causality relationship. First, investigating the order of integration, i.e., using the Unit root Test. After investigating the integrated level, the second step is to examine cointegrating vectors. In case any long-run association is indicated, then in the third step, the vector error correction model (VECM) is adopted, and finally, the Granger causality test is used. The VECM is used to describe short-run dynamics between variables from 1990 to 2019.

\subsection{Unit Root Test}

Time series data follows a unit root process, with the presence of unit root, further examination can give spurious results. This study applies a well-known unit root test Augmented Dickey-Fuller (ADF) for estimation of the integration order of variables.

\subsection{Co-integration Test}

For long-run relationships, the Johansen cointegration technique (1988) can be used as it is mostly used in empirical work. If variables have a unit root with a similar order of integration, then they can be cointegrated. The linear combination of $X_{t}$ and $Y_{t}$ can be shown in the following regression:

$$
\mathrm{Y}_{\mathrm{t}}=\alpha \mathrm{X}_{\mathrm{t}}+\mathrm{u}_{\mathrm{t}}
$$

And then taking residuals

$$
\mathrm{u}_{\mathrm{t}}=\mathrm{Y}_{\mathrm{t}}+\alpha \mathrm{X}_{\mathrm{t}}
$$

If $\mathrm{u}_{\mathrm{t}}$ is integrated at a level first, then $\mathrm{X}_{\mathrm{t}}$ and $\mathrm{Y}_{\mathrm{t}}$ are supposed to be cointegrated (Khan \& Bangash, 2013).

\subsection{Vector Error Correction Model (VECM)}

After concluding the cointegrated relationship between variables now short-run fluctuations can be measured by applying the Error Correction Model (ECM). The ECM is based on two equations listed as follows (Khan, Marimuthu, \& Lai, 2020): 


$$
\begin{aligned}
& \Delta \mathrm{GE}_{\mathrm{t}}=\alpha_{\bullet}+\alpha \mathrm{e}_{\mathrm{t}-1}+\sum \alpha_{\mathrm{i}} \Delta \mathrm{GE}_{\mathrm{t}-\mathrm{i}}+\sum \alpha_{\mathrm{i}} \Delta \mathrm{GR}_{\mathrm{t}-\mathrm{i}}+\sum \theta_{\mathrm{i}} \mathrm{GDP}_{\mathrm{t}-\mathrm{i}}+\mathrm{e}_{\mathrm{t}} \\
& \Delta \mathrm{GR}_{\mathrm{t}}=\alpha_{\bullet}+\beta \mathrm{u}_{\mathrm{t}-1}+\sum \mathrm{b}_{\mathrm{j}} \Delta \mathrm{GR}_{\mathrm{t}-\mathrm{j}}+\sum \mathrm{b}_{\mathrm{j}} \Delta \mathrm{GE}_{\mathrm{t}-\mathrm{j}}+\sum \theta_{\mathrm{j}} \mathrm{GDP}_{\mathrm{t}-\mathrm{j}}+\mathrm{h}_{\mathrm{t}}
\end{aligned}
$$

$e_{t-1}$ and $u_{t-1}$ are indicating the error correction terms, these are lagged residuals from the cointegration equation (2). Error correction terms indicate the speed of short-run adjustments to the long-run equilibrium. Further, the addition of GDP as an exogenous variable eliminates the problematic spurious causal properties because of the omission of significant variables from the examined association (Aziz, Habibullah, Azman-Saini, \& Azali, 2000).

\subsection{Granger Causality Model}

The Granger causal model for both GE and GR is defined as follows (Marimuthu, Khan, \& Bangash, 2021a).

$$
\begin{aligned}
& \Delta \mathrm{GE}_{\mathrm{t}}=\alpha_{\mathrm{s}}+\sum \alpha_{\mathrm{i}} \Delta \mathrm{GE}_{\mathrm{t}-\mathrm{i}}+\sum \alpha_{\mathrm{i}} \Delta \mathrm{GR}_{\mathrm{t}-\mathrm{i}}+\mathrm{e}_{\mathrm{t}} \\
& \Delta \mathrm{GR}_{\mathrm{t}}=\alpha_{\mathrm{s}}+\sum \mathrm{b}_{\mathrm{j}} \Delta \mathrm{GR}_{\mathrm{t}-\mathrm{j}}+\sum \mathrm{b}_{\mathrm{j}} \Delta \mathrm{GE}_{\mathrm{t}-\mathrm{j}}+\mathrm{h}_{\mathrm{t}}
\end{aligned}
$$

where GE and GR are stationary variables are presumed to be static in the time dimension. Further lag order of $\mathrm{j}$ is supposed to be identical for tested variables. The null hypothesis for Granger causality is that there is no causality exist between tested variables, while the alternative hypothesis is that there exists a Granger causality.

\section{Empirical Findings}

\subsection{Findings of Unit Root Test}

To check the causality the tested variables must be integrated of the same order, for this purpose investigation begins by applying the unit root in each variable. Results of the ADF test indicate that all three variables are non-stationary at the level. At first difference variables are stationary. Thus all three variables (GE, GR, and GDP are integrated at first difference I(1). The findings are stated in Table 1 .

Table 1. Findings of Unit Root Test

\begin{tabular}{|c|c|c|c|c|c|}
\hline Variables & level & Prob. & At first difference & Prob. & Integrated order \\
\hline GE & -2.51 & 0.32 & -3.87 & $0.00^{* * *}$ & I (1) \\
\hline GR & -2.03 & 0.55 & -4.07 & $0.01^{* *}$ & I (1) \\
\hline GDP & -2.06 & 0.54 & -4.24 & $0.01^{* *}$ & I (1) \\
\hline
\end{tabular}

Note: $* * *, * *$ represent significance level at $1 \%$ and $5 \%$ respectively, based on MacKinnon value (1996).

\subsection{Findings of Cointegration Test}

The Cointegration test is the succeeding step, after the unit root. Johansen cointegration test is applied to identify the cointegrating vectors. This study considers the trace and Maximum Eigenvalue (Max-Eigen) test to analyse the presence of a long-run association 
between GE and GR along with GDP as an exogenous variable. The following Table 2 reports the findings of the Max-Eigen and trace test which indicates the two cointegrating vectors among tested variables.

Table 2. Results of Cointegration Analysis

\begin{tabular}{|c|c|c|c|c|c|}
\hline Hypothesized & & Trace & Trace & Max-Eigen Test & \\
\hline No. of CE(s) & Eigenvalue & Statistic & Probability.** & Statistic value & $\begin{array}{c}\text { Probability. } \\
* *\end{array}$ \\
\hline None * & 0.376 & 21.355 & 0.0058 & 12.75 & $0.08^{*}$ \\
\hline At most $1 *$ & 0.272 & 8.600 & 0.0034 & 8.60 & $0.003 *$ \\
\hline
\end{tabular}

$* 2$ cointegrating vector(s) at the 0.05 level, ** represents a rejection of hypothesis at $5 \%$.

\subsection{Findings of Vector Error Correction Model (VECM)}

The results of VECM for GE (government expenditures) as a dependent variable illustrate the short-run variations. As stated in Table 3, 11\% of the error is corrected per year for GE. While VECM for GR (government revenues) as a dependent variable shows the short-run fluctuations and correcting $9 \%$ of error annually. Further results illustrate that government revenue is significantly affecting government expenditures in the short run. For both dependent variables, error correction terms are highly significant.

Table 3. Results of Vector Error Correction Test

\begin{tabular}{|c|c|c|}
\hline Error Correction & $\mathbf{D}(\mathbf{G E})$ & $\mathbf{D}(\mathbf{G R})$ \\
\hline \multirow{3}{*}{ Cointegration Equation 1 } & $\mathbf{- 0 . 1 1 3}$ & $\mathbf{0 . 0 9 5}$ \\
\cline { 2 - 3 } & $(0.025)$ & $(0.029)$ \\
\cline { 2 - 3 } & {$[4.521]$} & {$[3.270]$} \\
\hline \multirow{4}{*}{$\Delta \mathrm{GE}$} & 0.152 & 0.172 \\
\cline { 2 - 3 } & $(0.224)$ & $(0.260)$ \\
\cline { 2 - 3 } & {$[0.678]$} & {$[0.661]$} \\
\hline \multirow{4}{*}{$\Delta \mathrm{GR}$} & 0.639 & 0.401 \\
\cline { 2 - 3 } & $(0.247)$ & $(0.287)$ \\
\cline { 2 - 3 } & {$[2.584]$} & {$[1.396]$} \\
\hline \multirow{4}{*}{$\mathrm{C}$} & -72.302 & -60.313 \\
\cline { 2 - 3 } & $(17.129)$ & $(19.917)$ \\
\cline { 2 - 3 } & {$[-4.220]$} & {$[-3.028]$} \\
\hline \multirow{4}{*}{ GDP } & $1.16 \mathrm{E}-10$ & $9.80 \mathrm{E}-11$ \\
\cline { 2 - 3 } & $(2.5 \mathrm{E}-11)$ & $(2.9 \mathrm{E}-11)$ \\
\cline { 2 - 3 } & {$[4.729]$} & {$[3.433]$} \\
\hline
\end{tabular}

Note: GE: Government Expenditure, GR: Government Revenue, GDP: Gross Domestic Product, C: constant.

\subsection{Findings of Granger Causality}

Through VECM, it is clear that short-term fluctuations can be corrected by GR (as a dependent variable) and GE (as a dependent variable). The next step is to find out the Granger causality between GR and GE (Marimuthu, Khan, \& Bangash, 2021b). For this purpose, the VECM Granger causality test is used to disclose this causal relationship. The following Table 4 can represent that Government revenue causes government expenditures. 
While Government expenditures do not cause government revenues. So there is a unidirectional relationship running from GR to GE which is called Tax-spend Hypothesis.

Table 4. VEC Granger Causality

\begin{tabular}{|c|c|c|c|}
\hline Dependent variable: $\Delta \mathrm{GE}$ & Chi-square & df & Probability \\
\hline$\Delta$ GR & 6.682 & 1 & 0.009 \\
\hline Dependent variable: $\Delta \mathrm{GR}$ & Chi-square & df & Probability \\
\hline \multicolumn{4}{|c|}{} \\
\hline GE & 0.437 & 1 & 0.508 \\
\hline
\end{tabular}

Sample: from 1990 to 2019 , Observations: 28

\section{Discussion}

The main objectives of this analysis are to identify the causal association between GE and GR in southeast country Malaysia; further is to explore the fluctuations in the long-run and the short-run between the tested variables. To achieve the objectives, the study considered three variables to examine causal relationships, i.e., GE, GR, and GDP. As mentioned earlier, the GDP is used as an exogenous variable. Estimation included Unit root test for making the data stationary, Johansen cointegration test to investigate the long-run trends between the variables, after investigating the long-run association, VECM is used to find out the short-run fluctuations, and finally, Granger causality VECM based test is applied to check the causality direction between variables. All variables GDP, GE, and GR are integrated at the first difference I(1). Johanson Cointegration test indicated a long-run relationship between variables. In VECM short-run analysis, GR can affect GE significantly and $11 \%$ disequilibrium can be corrected in the short run. While GE has no significant impact on GR. The GDP has a significant impact on expenditures and revenues in the short run. In the long-run Granger Causality, the study investigated a uni-directional relationship from GR to GE. This means that in Malaysia government expenditures are supported by government revenues; Malaysian government expenditures depend upon revenues; according to revenues, the Government can decide the level of expenditures. So Tax-Spend Hypothesis which is introduced by (Friedman, 1978), is supported.

\section{Conclusion and Recommendations}

This study concludes that government revenues (GR) support government expenditures (GE) in Malaysia. The analysis reveals a unidirectional relationship between these two fiscal variables, i.e., expenditure and revenue. Also, this causal relation persists in the shortrun as well as in the long-run period. This analysis provides a suggestion for policymakers that Malaysia is not an economy where tax implementation is decided based on allocated government expenditures, but it is the revenue for the past two decades collected by the government which decides the levels of expenditures in the economy. Therefore, it is vital to consider expenditure levels by imposing tax rates because tax revenues will decide the level of government expenditures. Policymakers are not supposed to recommend a high tax rate to reduce the budget deficit because, in Malaysia, high tax revenues lead to high expenditures which can create unnecessary financial burdens and cause inflation in the economy. Fiscal illusion can also arise as mentioned by BW (Buchanan \& Wagner, 1977). According to them, a tax increase can cause a decrease in expenditure through the fiscal illusion. The fiscal illusion arises when taxpayer become more aggressive (due to high tax 
rate) towards government spending by lowering their quantity demand and formed a substitution effect.

\section{References}

Al-Khulaifi, A. S. (2012). The relationship between government revenue and expenditure in Qatar: A cointegration and causality investigation. International Journal of Economics and Finance, 4(9), 142148.

Aslan, M., \& Taşdemir, M. (2009). Is fiscal synchronization hypothesis relevant for Turkey? Evidence from cointegration and causality tests with endogenous structural breaks. Journal of Money, Investment and Banking, 12, 14-25.

Aziz, M. A., Habibullah, M. S., Azman-Saini, W., \& Azali, M. (2000). Testing for causality between taxation and government spending: An application of Toda-Yamamoto approach. Pertanika Journal of Social Science and Humanities, 8(1), 45-50.

Baghestani, H., \& McNown, R. (1994). Do revenues or expenditures respond to budgetary disequilibria? Southern Economic Journal, 311-322.

Barro, R. J. (1979). On the determination of the public debt. Journal of political Economy, 87(5, Part 1), 940-971.

Buchanan, J. M., \& Wagner, R. E. (1977). Democracy in deficit: The political legacy of Lord Keynes.

Buttiglione, L., Lane, P., Reichlin, L., \& Reinhart, V. (2014). Deleveraging, what deleveraging? The 16th Geneva Report on the world economy. International Center for Monetary and Banking Studies/Center for Economic Policy Research, September.

Chee, S. (1990). The political economy of governance: Why the Malaysian government has grown. The Malaysian economy in transition, 54-73.

Fasano, U., \& Wang, Q. (2002). Testing the relationship between government spending and revenue: Evidence from GCC countries.

Friedman, M. (1978). The limitations of tax limitation. Policy review(5), 7.

Hong, T. J. (2009). Tax-and-spend or spend-and-tax? Empirical evidence from Malaysia. Asian Academy of Management Journal of Accounting and Finance, 5(1), 107-115.

Irandoust, M. (2018). Government spending and revenues in Sweden 1722-2011: evidence from hidden cointegration. Empirica, 45(3), 543-557.

Jalil, A. Z. A., \& Harun, H. (2012). Fiscal decision and fiscal performance: The case of Kelantan and Penang. Procedia Economics and Finance, 1, 193-202. doi: doi.org/10.1016/S2212-5671(12)00023-8

Khan, H., \& Bangash, R. (2013). Nexus Between Microcredit and Poverty Alleviation: Time Series Evidence from Pakistan. Business \& Economic Review, 5(2), 1-13.

Khan, H., Marimuthu, M., \& Lai, F.-W. (2020). Fiscal deficit and its less inflationary sources of borrowing with the moderating role of political instability: Evidence from Malaysia. Sustainability, 12(1), 366.

Loganathan, N., \& Taha, R. (2007). Have Taxes Led Government Expenditure in Malaysia? Journal of International Management Studies, 2(2), 99-113.

Marimuthu, M., Khan, H., \& Bangash, R. (2021a). Fiscal Causal Hypotheses and Panel Cointegration Analysis for Sustainable Economic Growth in ASEAN. The Journal of Asian Finance, Economics, and Business, 8(2), 99-109.

Marimuthu, M., Khan, H., \& Bangash, R. (2021b). Reverse Causality between Fiscal and Current Account Deficits in ASEAN: Evidence from Panel Econometric Analysis. Mathematics, 9(10), 1124.

Mehrara, M., Pahlavani, M., \& Elyasi, Y. (2011). Government revenue and government expenditure nexus in Asian countries: Panel cointegration and causality. International Journal of Business and Social Science, 2(7), 199-207.

Meltzer, A. H., \& Richard, S. F. (1981). A rational theory of the size of government. Journal of political Economy, 89(5), 914-927.

Musgrave, R. (1966). Principles of budget determination. Public finance: Selected readings, 15-27.

Mutascu, M. (2015). A bootstrap panel Granger causality analysis of government revenues and expenditures in the PIIGS countries.

Narayan, P. K., \& Narayan, S. (2006). Government revenue and government expenditure nexus: evidence from developing countries. Applied Economics, 38(3), 285-291.

Peacock, A. T., \& Wiseman, J. (1979). Approaches to the analysis of government expenditure growth. Public Finance Quarterly, 7(1), 3-23.

Reinhart, C. M., \& Rogoff, K. S. (2010). Growth in a Time of Debt. American Economic Review, 100(2), 573-578.

Roberts, P. C. (1978). Idealism in public choice theory. Journal of Monetary Economics, 4(3), 603-615.

Ullah, N. (2016). The Relationship of Government Revenue and Government Expenditure: A case study of Malaysia. 